\title{
菌状息肉症に対する $\mathrm{OH}-6000$ 後期臨床第 II 相試験
}

\author{
石原 和之*
}

\section{Summary}

A late phase II study of $\mathrm{OH}-6000$ consisting of two phases, one to find the optimal dosage and regimen and the other to evaluate the clinical efficacy at the optimal dosage and regimen, was performed in patients with mycosis fungoides. This study was a multicenter study including 42 medical institutions nationwide. The drug was administered by the intramuscular route at a daily dose of $1 \times 10^{6}$ or $2 \times 10^{6} \mathrm{IU}, 3$ times a week on alternating days or 5 consecutive days a week.

The optimal dosage and regimen was determined to be $1 \times 10^{6}$ or $2 \times 10^{6} \mathrm{IU}$, adjusted for adverse reactions and severity of symptoms, administered at least 5 consecutive days a week, for 8 or more successive weeks. Therefore, the latter phase of the study was performed with this dosage and regimen.

Of a combined total of 38 completed cases in both study phases, complete response (CR) was observed in 3 and partial response (PR) in 19, for an overall response rate of $57.9 \%$. The response rates in the individual study phases were $41.2 \%(7 / 17)$ in the dosage and regimen-finding phase and $71.4 \%$ (15/21) in the efficacy-evaluation phase.

Adverse reactions were those commonly observed with other IFN- $\gamma$; none were serious and all were reversible.

In conclusion, $\mathrm{OH}-6000$ was considered to be a highly useful drug in the treatment of mycosis fungoides.

\section{は じめに}

$$
\text { インターフェロン（以後 IFN）はウイルス感 }
$$
染に対して干渉する物質として1957年に発見 ${ }^{11}$ されて以来多くの研究がなされてきた。すなわ ち, IFN は抗原性の違いにより 3 つのタイプ $\alpha, \beta, \gamma$ が存在し ${ }^{2)}, \gamma$ は $\alpha, \beta$ とは異なるレセプ

\footnotetext{
* Kazuyuki ISHIHARA：国立がんセンター中央病 院皮膚科 $(\mathrm{OH}-6000$ 皮膚恶性腫瘍部会代表)
}

ターを介すること ${ }^{3)}, \gamma$ は抗ウイルス効果や抗腫 瘍効果において $\alpha, \beta$ と異なったスペクトラム や強さを有することが知られており ${ }^{4}$, その臨 床応用が期待されている。既に, 遺伝子組換え 型 IFN- $\gamma$ ではいくつかの臨床試験が行われて いるが5)6), 天然型 IFN- $\gamma$ については大量生産 の障壁により十分な検討がなされていないのが 現状である。

OH-6000は, 侏林原生物化学研究所により開 発されたin vivo 培養法を用いて大量に培養さ れたヒトミエロモノサイト細胞株（HBL-38細 
胞）に，誘発剤としてリポポリサッカライドを 刺激することで大量に産生された後精製して得 られた天然型 IFN- $\gamma$ である778)。既に各種悪性 腫瘍患者を対象とした前期臨床第 II相試験を実 施し ${ }^{9)}$ ，本剂が菌状息肉症に対して効果を有す ることが示唆されている。

菌状息肉症は，皮膚 $\mathrm{T}$ 細胞リンパ腫の代表的 なもので慢性の経過をたどるが最終的な予後は 不良である。治療法としてステロイド外用， PUVA，放射線および化学療法により一時的軽 快は得られるものの, 再発は避けられず治㾍は 期待できないため，新たな治療法が望まれてい る。

そこで今回, OH-6000の菌状息肉症患者に対 する適切な用法用量を設定し, 更にその用法用 量での臨床効果の検討を目的とした後期臨床第 II相試験を行ったので，その結果を報告する。

\section{対象および方法}

\section{1. 組織および期間}

全国42施設による $\mathrm{OH}-6000$ 研究会皮膚悪性 腫瘍部会および効果・安全性評価委員会を組織 し（表 1 施設 総括医師 判定委員 コント ローラー 効果安全性評価委員), 1990年12月よ ク1993年 9 月まで実施した。

\section{2. 対象症例}

対象は菌状息肉症の患者であり，以下に対象 症例の条件を示した。

(1)原則として, 組織学的, 細胞学的に悪性腫 瘍であることが確認されている者

(2)測定可能または評価可能病変を有する者

(3)主要藏器 (心, 肺, 肝, 腎, 骨䯣など) の 機能が十分保持されている者。ただし，下記の 条件に合致することを原則とする

- 白血球数 $\geqq 4000 / \mathrm{mm}^{3}$

- GOT, GPT 正常値の 2 倍

・血清クレアチニン $\leqq 2.0 \mathrm{mg} / \mathrm{dl}$

(4)活動性の重複癌のない者

(5)重篤な合併症のない者
(6)一般状態（Performance Status）が0〜3の 者

(7)少なくとも 3 力月以上生存可能と判断され る者

(8)前治療による効果および副作用の影響が持 ち越されていない者（原則として前治療が 4 週 間以上前に終了している者)

(9)性別不問，原則として年齢が16歳以上， 75 歳未満の者

また，下記の条件に該当する症例は対象より 除外した。

(1)妊婦，授乳婦および妊娠している可能性の ある者

(2)アレルギー性素因を有する者

(3)ワクチン等生物学的製剂に対し，過敏な反 応を示した経験を有する者

(4)プリック試験陽性の者

(5)その他, 試験担当医師が不適格と判断した 者

なお，試験担当医師は試験に先立ち患者もし くは代理人に適切な説明を行い, 文書または口 頭での同意を得た。

\section{3. 試験薬剤}

1 バイアル当たりヒト IFN- $\gamma$ (治験薬コー ド：OH-6000）として100万 IU を含有する凍結 乾燥製剂を用いた。なお，製剤は大塚製薬株式 会社より提供された。

\section{4. 試験方法}

\section{1 ) 用法用量の検討}

原則として, 100万 IU あるいは200万 IUを 1 日 1 回連日 8 週間以上の筋肉内投与とした。な お，症例登録および投与量の指示方法は電話登 録法を用いた。すなわち, 試験担当医師が本試 験に該当する患者と判断した場合に登録セン ター（侏べルシステム24）に電話連絡し, 症例 の適格性の確認をしたのち, 登録センターはコ ントローラーにより予め作成された「割付け表」 に従い登録順に投与量の指定を行った。

\section{2 ) 臨床効果の検討}

1 ）の試験にて設定された本剂の適切な臨床 
表1-1 OH-6000研究会皮虞悪性腫場部会（順不同）

\begin{tabular}{|c|c|c|c|c|c|c|c|c|c|}
\hline 設 名 & \multicolumn{2}{|c|}{ 科 } & 名 & \multicolumn{2}{|r|}{ 代 } & 表 & 兵 & 名 & \\
\hline 北海道大学医学部 & 皮 & 膚 & 科 & 大河原 & 章 & & & & \\
\hline 札幌医科大学 & 皮 & 膚 & 科 & 高橋 & 誠 & & & & \\
\hline 市立室蘭総合病院 & 皮 & 膚 & 科 & 石田 & 修 & & & & \\
\hline 東北大学医学部 & 皮 & 䖉 & 科 & 田上 & 八朗 & & & & \\
\hline 埼玉医科大学 & 皮 & 䖉 & 科 & 池田 & 重雄 & 拧 & s & & \\
\hline 埼玉医科大学総合医療センター & 皮 & 膚 & 科 & 北村 & 啓次郎 & & & & \\
\hline 東京大学医学部 & 皮 & 膚 & 科 & 石橋 & 康正 & & & & \\
\hline 国立がんセンター中央病院 & 皮 & 䖉 & 科 & 石原 & 和之 & & 大实 & & \\
\hline 虎の門病院 ～～～～～～ & 皮 & 膚 & 科 & 大原 & 国章 & & & & \\
\hline 横浜市立大学医学部（浦舟） & 皮 & 膚 & 科 & 池澤 & 善郎 & & & & \\
\hline 横浜市立大学医学部 & 皮 & 膚 & 科 & 中嶋 & 弘 & is & S & & \\
\hline 聖マリアンナ医科大学 & 皮 & 膚 & 科 & 溝口 & 昌子 & & & & \\
\hline 北里大学 ～～～～～～～～～～ & 皮 & 虚 & 科 & 西山 & 茂夫 & & & & \\
\hline 横浜栄共済病院 & 皮 & 膚 & 科 & 毛利 & 忍 & & （現 & 杉山 & 朝美） \\
\hline 信州大学医学部 & 皮 & 䖉 & 科 & 斎田 & 俊明 & & & & \\
\hline 北信総合病院 & 皮 & 䖉 & 科 & 土肥 & 庄二郎 & & & & \\
\hline 新潟大学医学部 & 皮 & 虞 & 科 & 伊藤 & 雅章 & & & & \\
\hline 浜松医科大学 & 皮 & 膚 & 科 & 瀧川 & 雅浩 & & & & \\
\hline 名古屋大学医学部分院 & 皮 & 䖉 & 科 & 早川 & 律子 & & & & \\
\hline 岐阜大学医学部 & 皮 & 䖉 & 科 & 森 & 俊二 & $\hat{3}$ & ف & & \\
\hline 三重大学医学部 & 皮 & 䖉 & 科 & 清水 & 正之 & & & & \\
\hline 京都大学医学部 & & 学 & 毒学 & 今村 & 貞夫 & & & & \\
\hline 大阪市立大学医学部 & 皮 & 膚 & 科 & 濱田 & 稔夫 & & & & \\
\hline 大阪大学医学部 & 皮 & 虞 & 科 & 吉川 & 邦彦 & & & & \\
\hline 北野病院 & 皮 & 膚 & 科 & 河村 & 甚郎 & & & & \\
\hline 大阪赤十字病院 & 皮 & 虞 & 科 & 早川 & 實 & & & & \\
\hline 近畿大学医学部 & 皮 & 膚 & 科 & 手塚 & 正 & & & & \\
\hline 近畿大学農学部 & & & & 米虫 & 節夫 & (a) & D & & \\
\hline 和歌山県立医科大学 & 皮 & 䖉 & 科 & 青木 & 和夫 & & （現 & 松中 & 成浩） \\
\hline 天理よろづ相談所 & 皮 & 䖉 & 科 & 宮地 & 良樹 & & (現 & 佐山 & 重敏） \\
\hline 神戸市立中央市民病院 & 皮 & 膚 & 科 & 土井 & 顕 & & & & \\
\hline 岡山大学医学部 & 皮 & 膚 & 科 & 荒田 & 次郎 & & & & \\
\hline 倉敷中央病院 & 皮 & 膚 & 科 & 宮内 & 束光 & & & & \\
\hline 広島大学医学部 & 皮 & 膚 & 科 & 山本 & 昇壯 & & & & \\
\hline 香川医科大学 & 皮 & 虞 & 科 & 高岩 & 堯 & & & & \\
\hline 九州大学医学部 & 皮 & 膚 & 科 & 堀 & 嘉昭 & & & & \\
\hline 国立福岡中央病院 & 皮 & 膚 & 科 & 安田 & 勝 & & & & \\
\hline 福岡赤十字病院 & 皮 & 膚 & 科 & 武石 & 正昭 & & & & \\
\hline 長崎大学医学部 & 皮 & 膚 & 科 & 吉田 & 彦太郎 & & & & \\
\hline 熊本大学医学部 & 皮 & 膚 & 科 & 小野 & 友道 & & & & \\
\hline 宮崎医科大学 & 皮 & 膚 & 科 & 井上 & 勝平 & & & & \\
\hline 鹿児島大学医学郎 & 皮 & 膚 & 科 & 田代 & 正昭 & & （現 & 神崎 & 保) \\
\hline 琉球大学医学部 & 皮 & 膚 & 科 & 名嘉真 & 武男 & (故)（列 & （現 & 野中 & 薫雄） \\
\hline
\end{tabular}

：試験総括医師（皮䖉悪性腫瘍部会世話人）引：判定委員 ○：コントローラー

表1-2＼cjkstart効果・安全性評価委員会（順不同）

\begin{tabular}{l|llr}
\hline 東京都駒込赤十字血液センタ- & 副所長 & 中尾 & 功 \\
浜松医科大学 & 病院長 & 山田 & 瑞穂 \\
熊本大学医学部 & 病院長 & 高月 & 清 \\
\hline
\end{tabular}


用法用量にて行った。なお, 症例の登録は本研 究会事務局にて電話登録により行い, 症例の適 格性の確認をした。

\section{3 ) 併用禁止}

試験薬剂投与中および投与終了後の経過観察 中は, 他の癌化学療法剂, 免疫療法剂およびホ ルモン療法剤等の抗腫瘍剂の併用や, 放射線療 法や手術等の抗腫瘍療法の併用を禁止した。な お, 解熱剤については子防投与および治療投与 は差し支えないこととした。

\section{5. 観察・検査項目および時期}

以下の項目について投与前, 投与中, 投与終 了後に観察・検査を実施した。

(1)皮膚の測定可能または評価可能病変

(2)皮膚以外の病変の有無および病変の推移 (肺，肝，リンパ節，骨等を全身シンチ，X 線, CT，エコーなどにより検査・観察)

(3)自他覚的症状

(4)臨床検査

(5)抗 IFN- $-\gamma$ 抗体価および抗異種蛋白抗体価

(6)血中濃度および免疫学的検査は可能な場合 のみ実施

\section{6. 症例の取扱いおょび効果判定}

症例の取扱いは「固形がん化学療法直接効果
判定基準 ${ }^{10)}$ の症例の取扱いに準じ, 効果の判定 は「皮膚悪性腫瘍における固形がん薬物療法効 果判定基準」 ${ }^{11)}$ に準じて判定委員会で決定した。 なお, 副作用の重篤度の判定は「固形がん化学 療法効果増強の判定基準」 ${ }^{12)}$ の副作用の記載様 式に従った。

\section{7. 試験の進行}

中間検討を行った際に, 有効性と安全性の見 地から試験の継続の可否について効果安全性評 価委員会の助言を受けて試験を進めた。

\section{成 績}

\section{1. 対象症例}

試験の登録例は44例で，その内訳は用法用量 の検討で20例, 臨床効果の検討で24例であった。 44例中, 対象外疾患である ATLの 1 例と前治 療終了から試験開始までの期間が 4 週間未満の 症例 2 例を不適格例とした。適格例41例のうち， 副作用のため 4 週間未満で投与を中止した 3 例 を中止例とし, その内容は 1 例が僚怠感のため, 1 例が白血球減少と GOT, GPT 上昇のため, 残りの 1 例は白血球減少のためであった。なお, 病変が増大したため 4 週間未満で投与を終了し

表 2. 症例の取扱い

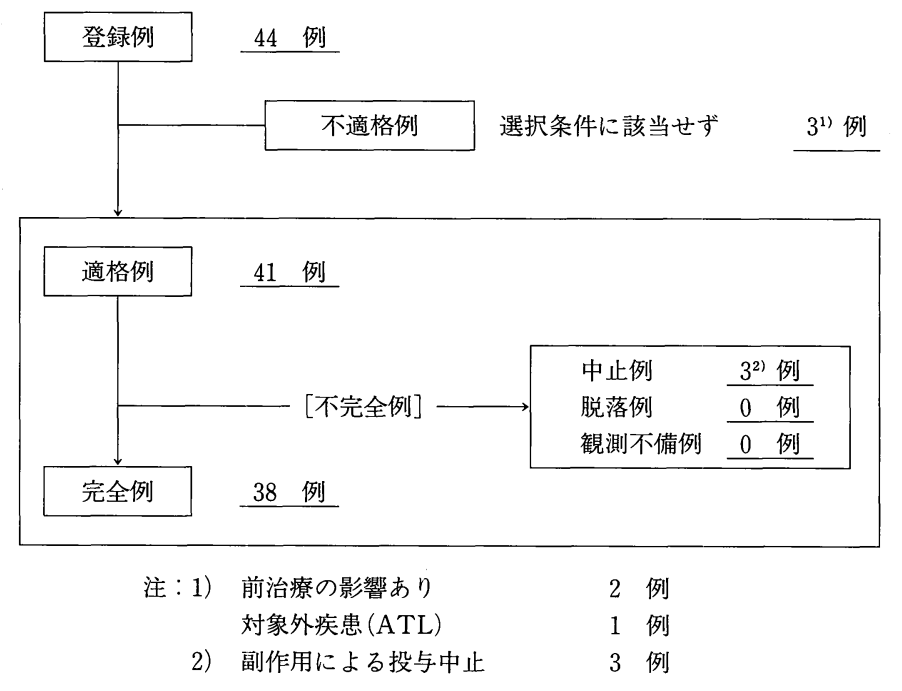


た 1 例と，副作用によりいったん休薬としたが 病変が消失しつつあったためその後再投薬せず にそのまま 4 週間未満で投与を終了し，かつ， その後の経過観察が十分に行われた 1 例は完全 例とした。以上の症例の取扱い結果を表 2 に示 す。

すなわち，適格例41例を安全性の評価対象と し，完全例の38例を有効性の評価対象とした。 完全例38例の内訳は，用法用量の検討で17例， 臨床効果の検討で21例であった。更に用法用量 の検討例 17 例のうち, 100 万 IU 投与例は 8 例, 200 万 IU 投与例は 9 例であったが, 200 万 IU 投 与例のうち 2 例は副作用 (白血球減少) のため 4 週間未満（8日，16日）で100万 IUに減量し たため，200万 IU の有効性評価対象からは除い た。従って, 用量別の有効性評価対象例は 100 万 IU 8 例, 200万 IU 7 例として集計した。完全例 および用量別有効性評価対象例の患者背景を表 3 に示す。

\section{2. 用法用量の検討}

\section{1 ) 用量別検討}

患者背景では, ステージで100万 IU 群の方が 200万 IU 群に比べて進行した症例がやや多 かったが，それ以外の背景には偏りは認められ なかった。投与量別抗腫瘍効果を表 4 に示す。 奏効率は 100 万 IU $37.5 \%$ (3/8)，200万 IU $42.9 \%$ (3/7) と，投与量による大きな差は認められな かった。なお，100万 IU を 8 週間投与したが効 果 MR で PR に達しなかったため, 4 週間の休 薬後 200 万 IU を投与し効果 $\mathrm{PR}$ となった症例 が 1 例あり，この症例の取扱いは用量別有効性 解析では 100 万 IU 群, MR 例として, 有効性解 析では PR 例として集計した。用量別の自他覚 症状, 臨床検査值異常を表 5 に示す。自他覚症 状では用量間に特に差はなかったが, 臨床検査 值異常では GOT, GPT, LDH, CPK の上昇で 200 万 IU 群の方が100万 IU 群に比べて発現頻 度がやや高かった。副作用による中止例は 2 例 で，1例は 100 万 IU 群, 残りの 1 例は 200 万 IU 群であった。中止理由は，1例が全身倦怠感，
1 例が白血球減少および $\mathrm{GOT} \cdot \mathrm{GPT}$ 上昇によ るものであった。

\section{2 ）投与頻度別検討}

投与頻度別抗腫瘍効果を表 4 に示す。奏効率 は，連日投与 (週 5 日以上投与) では $45.5 \%$ (5/ 11)，隔日投与（週3～4日投与）では $33.3 \% （ 2 /$

6）と，連日投与でやや高かった。

\section{3 ）効果発現までの期間と PR 奏効期間}

奏効例における PR 開始時点までの期間は, 100万 IU 群の奏効例でそれぞれ20日，33日，34 日で，200万 IU 群の奏効例でそれぞれ28日，35 日，42日であった。なお，100万 IU 投与後200万 IUに増量して PR となった 1 例では，119日で あった。PR 奏効期間は, 100 万 IU 群の奏効例で それぞれ36日 $(+) ， 73$ 日 $(+) ， 81$ 日 $(+) て ゙ ， 200$ 万 IU 群の奏効例でそれぞれ29日 $(+)$ ，36日 $(+)$ ，182日 $(+)$ であった。なお，100万 IU 投与 後200万 IUに増量して PR となった 1 例では, 119日（十）であった。

\section{4 ) 判定委員会の結論}

以上のことから，本剤の臨床効果を検討する ための適切な用法用量として，以下のように判 定委員会で結論された。すなわち，1 日 1 回100 万 IU あるいは200万 IU を副作用，病勢により 適宜増減しながら原則として連日筋肉内投与す る。投与期間は原則として 8 週間以上とする。

\section{5 ) 効果安全性評価委員会の助言}

用法用量の検討を終了した時点で，効果安全 性評価委員会に有効性と安全性の見地から試験 の継続の可否について助言を受けた。その結果, 更に試験を継続することは妥当であると判断さ れた。

\section{3. 臨床効果の検討}

用法用量として「1日 1 回100万 IU あるいは 200 万 IU を副作用, 病勢により適宜増減しなが ら原則として連日筋肉内投与する。投与期間は 原則として 8 週間以上とする。」により, 更に本 剂の臨床効果を検討した。

抗腫瘍効果は, 完全例21例中 CR 3 例, PR12 例に認められ，奏効率は $71.4 \%$ であった（表 6 )。 
表 3．完全例および用量別有効性評価対象例患者背景

\begin{tabular}{|c|c|c|c|c|c|c|c|}
\hline \multirow{2}{*}{ 項 } & \multirow{2}{*}{ 目 } & \multirow[b]{2}{*}{ 計 } & \multicolumn{4}{|c|}{ 用法用量の検討 } & \multirow{2}{*}{$\begin{array}{c}\text { 臨床効果 } \\
\text { の検討 }\end{array}$} \\
\hline & & & 100 & 200 & $\begin{array}{l}\text { 検定方法および } \\
\text { 検定結果 }\end{array}$ & 完全例 & \\
\hline \multirow[b]{2}{*}{ 性 } & 計 & 38 & 8 & 7 & & $17^{\text {æ } 1,2)}$ & 21 \\
\hline & $\begin{array}{l}\text { 男 } \\
\text { 女 }\end{array}$ & $\begin{array}{l}19 \\
19\end{array}$ & $\begin{array}{l}2 \\
6\end{array}$ & $\begin{array}{l}3 \\
4\end{array}$ & $\begin{array}{c}\text { Fisher } \\
\mathrm{p}=0.608\end{array}$ & $\begin{array}{c}5 \\
12^{\text {i1,2) }}\end{array}$ & $\begin{array}{r}14 \\
7\end{array}$ \\
\hline $\begin{array}{l}\text { 年 } \\
\text { (歳) }\end{array}$ & $\begin{array}{r}\sim 40 \\
40 \sim 49 \\
50 \sim 59 \\
60 \sim 69 \\
70 \text { 以上 }\end{array}$ & $\begin{array}{r}5 \\
10 \\
6 \\
8 \\
9\end{array}$ & $\begin{array}{l}1 \\
2 \\
2 \\
1 . \\
2\end{array}$ & $\begin{array}{l}2 \\
1 \\
2 \\
1 \\
1\end{array}$ & $\begin{array}{c}\mathrm{U} \text { 検定 } \\
\mathrm{p}=0.636\end{array}$ & $\begin{array}{l}5^{\text {方,2) }} \\
3 \\
4 \\
2 \\
3\end{array}$ & $\begin{array}{l}0 \\
7 \\
2 \\
6 \\
6\end{array}$ \\
\hline PS & $\begin{array}{l}0 \\
1\end{array}$ & $\begin{array}{r}34 \\
4\end{array}$ & $\begin{array}{l}7 \\
1\end{array}$ & $\begin{array}{l}7 \\
0\end{array}$ & $\begin{array}{c}\mathrm{U} \text { 検定 } \\
\mathrm{p}=0.423\end{array}$ & $\begin{array}{l}16^{\text {泣,2) }} \\
1\end{array}$ & $\begin{array}{r}18 \\
3\end{array}$ \\
\hline ステージ & $\begin{array}{l}\text { IA } \\
\text { IB } \\
\text { IIA } \\
\text { IIB } \\
\text { III } \\
\text { IVA } \\
\text { IVB }\end{array}$ & $\begin{array}{r}4 \\
21 \\
2 \\
8 \\
2 \\
0 \\
1\end{array}$ & $\begin{array}{l}0 \\
2 \\
0 \\
5 \\
1 \\
0 \\
0\end{array}$ & $\begin{array}{l}0 \\
5 \\
0 \\
2 \\
0 \\
0 \\
0\end{array}$ & $\begin{array}{c}\mathrm{U} \text { 検定 } \\
\mathrm{p}=0.0807\end{array}$ & $\begin{array}{l}0 \\
9^{\text {\#1,2) }} \\
0 \\
7 \\
1 \\
0 \\
0\end{array}$ & $\begin{array}{r}4 \\
12 \\
2 \\
1 \\
1 \\
0 \\
1\end{array}$ \\
\hline 臨床病期 & $\begin{array}{c}\text { 紅斑期 } \\
\text { 扁平浸潤期 } \\
\text { 腫瘤期 }\end{array}$ & $\begin{array}{r}4 \\
25 \\
9\end{array}$ & $\begin{array}{l}0 \\
3 \\
5\end{array}$ & $\begin{array}{l}0 \\
5 \\
2\end{array}$ & $\begin{array}{c}\mathrm{U} \text { 㭘定 } \\
\mathrm{p}=0.229\end{array}$ & $\begin{array}{l}0 \\
10^{\text {it } 1,2)} \\
7\end{array}$ & $\begin{array}{r}4 \\
15 \\
2\end{array}$ \\
\hline 合 併 症 & $\begin{array}{l}\text { なし } \\
\text { あり }\end{array}$ & $\begin{array}{l}25 \\
13\end{array}$ & $\begin{array}{l}5 \\
3\end{array}$ & $\begin{array}{l}6 \\
1\end{array}$ & $\begin{array}{c}\text { Fisher } \\
\mathrm{p}=0.569\end{array}$ & $\begin{array}{l}13^{\text {æ1 } 1,2)} \\
4\end{array}$ & $\begin{array}{r}12 \\
9\end{array}$ \\
\hline 前 治 療 & \begin{tabular}{ll} 
無 & \\
有 & \\
\hdashline & ステロイド \\
PUVA & 有 \\
& 放射線 \\
& BRM
\end{tabular} & $\begin{array}{r}22 \\
16 \\
- \\
7 \\
7 \\
11 \\
6\end{array}$ & \begin{tabular}{|c|}
4 \\
4 \\
- \\
3 \\
2 \\
3 \\
2
\end{tabular} & \begin{tabular}{c}
4 \\
3 \\
\hdashline- \\
2 \\
1 \\
2 \\
1
\end{tabular} & $\begin{array}{c}\text { Fisher } \\
\mathrm{p}=1,000\end{array}$ & 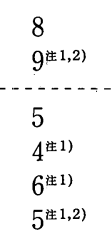 & $\begin{array}{r}14 \\
7 \\
2 \\
3 \\
5 \\
1\end{array}$ \\
\hline 併 用 薬 & $\begin{array}{l}\text { 無 } \\
\text { 有 }\end{array}$ & $\begin{array}{r}8 \\
30\end{array}$ & $\begin{array}{l}2 \\
6\end{array}$ & $\begin{array}{l}1 \\
6\end{array}$ & $\begin{array}{c}\text { Fisher } \\
\mathrm{p}=1.000\end{array}$ & $\begin{array}{c}3 \\
14^{\text {\#1,2) }}\end{array}$ & $\begin{array}{r}5 \\
16\end{array}$ \\
\hline $\begin{array}{l}\text { 投与期間 } \\
\text { (週) }\end{array}$ & \begin{tabular}{c}
\multicolumn{3}{c}{66} \\
$6<\leqq 8$ \\
$8<\leqq 10$ \\
$10<\leqq 12$ \\
$12<$
\end{tabular} & $\begin{array}{r}9 \\
13 \\
4 \\
1 \\
11\end{array}$ & $\begin{array}{c}2^{\text {i3 } 3} \\
3^{\text {is } 4)} \\
0 \\
0 \\
3\end{array}$ & $\begin{array}{l}1 \\
4 \\
0 \\
0 \\
2\end{array}$ & $\begin{array}{c}\mathrm{U} \text { 検定 } \\
\mathrm{p}=0.950\end{array}$ & $\begin{array}{l}2 \\
9^{\text {: } 1,2,3)} \\
0 \\
0 \\
6^{\text {站4) }}\end{array}$ & $\begin{array}{l}7 \\
4 \\
4 \\
1 \\
5\end{array}$ \\
\hline 用 & $\begin{array}{c}100 \\
100,200 \\
200\end{array}$ & $\begin{array}{l}12 \\
12 \\
14\end{array}$ & $\begin{array}{c}6 \\
2^{\sharp 3,4)} \\
0\end{array} \mid$ & $\begin{array}{l}0 \\
0 \\
7\end{array}$ & & $\begin{array}{l}6 \\
4^{\text {(ฆ1,2) }} \\
7\end{array}$ & $\begin{array}{l}6 \\
8 \\
7\end{array}$ \\
\hline 用 法 & $\begin{array}{l}\text { 5 7日/週 } \\
\text { 3 4日/週 } \\
\text { 1 } 2 \text { 日/週 }\end{array}$ & $\begin{array}{r}28 \\
9 \\
1\end{array}$ & $\begin{array}{c}7^{\text {社4) }} \\
1 \\
0\end{array}$ & $\begin{array}{l}5 \\
2 \\
0\end{array}$ & $\begin{array}{c}\mathrm{U} \text { 検定 } \\
\mathrm{p}=0.505\end{array}$ & $\begin{array}{l}11 \\
6^{\text {住 } 1,2,4)} \\
0\end{array}$ & $\begin{array}{r}17 \\
3 \\
1\end{array}$ \\
\hline
\end{tabular}

注 1 ）短期間（8日）で用量変更のため用量別比較からは除外した 1 例を含む。

注 2 ) 短期間（16日）で用量変更のため用量別比較からは除外した 1 例を含む。

注 3 ） 100 万 4 週間投与後, 200 万 4 週間投与例の 1 例を含む。

注 4 ） 100 万 8 週間投与後， 4 週間休薬したのち 200 万 8 週間以上投与例の 1 例を含む。 
表 4. 用法用量別抗腫瘍効果

\begin{tabular}{|c|c|c|c|c|c|c|c|c|c|}
\hline & & 計 & $\mathrm{CR}$ & PR & MR & $\mathrm{NC}$ & PD & 奏効率(\%) & $\begin{array}{l}\text { 検定方法および } \\
\text { 検定結果 }\end{array}$ \\
\hline \multirow{2}{*}{ 投 与 量 } & 100万 IU & 8 & 0 & 3 & 1 & 3 & 1 & 37.5 & \multirow{2}{*}{$\begin{array}{c}\text { Fisher } \\
p=1.000\end{array}$} \\
\hline & 200 万 IU & 7 & 0 & 3 & 1 & 3 & 0 & 42.9 & \\
\hline \multirow{2}{*}{ 投与頻度 } & 週5日以上 & 11 & 0 & 5 & 0 & 5 & 1 & 45.5 & \\
\hline & 週3～4日 & 6 & 0 & 2 & 1 & 3 & 0 & 33.3 & \\
\hline
\end{tabular}

注）投与頻度は完全例17例で集計した。

表 5. 用量別の自他覚症状, 臨床検査值異常

\begin{tabular}{|c|c|c|c|c|c|c|c|c|c|c|c|c|c|}
\hline \multicolumn{2}{|c|}{ 投与 量 } & \multicolumn{4}{|c|}{100 万 IU } & \multicolumn{4}{|c|}{200 万 IU } & \multicolumn{4}{|c|}{ 全 } \\
\hline 例 & 数 & \multicolumn{4}{|c|}{9} & \multicolumn{4}{|c|}{10} & \multicolumn{4}{|c|}{19} \\
\hline 種類/程度注) & & 1 & 2 & 3 & 計 & 1 & 2 & 3 & 計 & 1 & 2 & 3 & 計 \\
\hline $\begin{array}{l}\text { 皮膚· } \\
\text { 皮膚付属器障害 }\end{array}$ & 発疹 & 0 & 1 & 0 & 1 & 0 & 0 & 0 & 0 & 0 & 1 & 0 & $1(5.3)$ \\
\hline $\begin{array}{l}\text { 中枢· } \\
\text { 末梢神経系障害 }\end{array}$ & 頭痛 & 1 & 0 & 0 & 1 & 1 & 0 & 0 & 1 & 2 & 0 & 0 & $2(10.5)$ \\
\hline 消化管障害 & $\begin{array}{l}\text { 悪心 } \\
\text { 食欲不振 } \\
\text { 腹部不快感 }\end{array}$ & $\begin{array}{l}0 \\
0 \\
0\end{array}$ & $\begin{array}{l}0 \\
0 \\
1\end{array}$ & $\begin{array}{l}0 \\
0 \\
0\end{array}$ & $\begin{array}{l}0 \\
0 \\
1\end{array}$ & $\begin{array}{l}2 \\
1 \\
0\end{array}$ & $\begin{array}{l}0 \\
0 \\
0\end{array}$ & $\begin{array}{l}0 \\
0 \\
0\end{array}$ & $\begin{array}{l}2 \\
1 \\
0\end{array}$ & $\begin{array}{l}2 \\
1 \\
0\end{array}$ & $\begin{array}{l}0 \\
0 \\
1\end{array}$ & $\begin{array}{l}0 \\
0 \\
0\end{array}$ & $\begin{array}{l}2(10.5) \\
1(5.3) \\
1(5.3)\end{array}$ \\
\hline 一般的全身障害 & $\begin{array}{l}\text { 発熱 } \\
\text { 全身倦怠感 }\end{array}$ & $\begin{array}{l}2 \\
3\end{array}$ & $\begin{array}{l}5 \\
4\end{array}$ & $\begin{array}{l}0 \\
0\end{array}$ & $\begin{array}{l}7 \\
7\end{array}$ & $\begin{array}{l}5 \\
5\end{array}$ & $\begin{array}{l}4 \\
0\end{array}$ & $\begin{array}{l}0 \\
0\end{array}$ & $\begin{array}{l}9 \\
5\end{array}$ & $\begin{array}{l}7 \\
8\end{array}$ & $\begin{array}{l}9 \\
4\end{array}$ & $\begin{array}{l}0 \\
0\end{array}$ & $\begin{array}{l}16(84.2) \\
12(63.2)\end{array}$ \\
\hline 適用部位障害 & 投与部熱感 & 1 & 0 & 0 & 1 & 0 & 0 & 0 & 0 & 1 & 0 & 0 & $1(5.3)$ \\
\hline $\begin{array}{l}\text { 肝臟・ } \\
\text { 胆管系障害 }\end{array}$ & $\begin{array}{l}\text { GOT 上昇 } \\
\text { GPT 上年 } \\
\text { LDH 上昇 } \\
\text { ALP 上昇 }\end{array}$ & $\begin{array}{l}1 \\
1 \\
1 \\
0\end{array}$ & $\begin{array}{l}1 \\
1 \\
0 \\
0\end{array}$ & $\begin{array}{l}0 \\
0 \\
0 \\
0\end{array}$ & $\begin{array}{l}2 \\
2 \\
1 \\
0\end{array}$ & $\begin{array}{l}6 \\
5 \\
1 \\
0\end{array}$ & $\begin{array}{l}0 \\
0 \\
2 \\
1\end{array}$ & $\begin{array}{l}0 \\
0 \\
0 \\
0\end{array}$ & $\begin{array}{l}6 \\
5 \\
3 \\
1\end{array}$ & $\begin{array}{l}7 \\
6 \\
2 \\
0\end{array}$ & $\begin{array}{l}1 \\
1 \\
2 \\
1\end{array}$ & $\begin{array}{l}0 \\
0 \\
0 \\
0\end{array}$ & $\begin{array}{l}8(42.1) \\
7(36.8) \\
4(21.1) \\
1(5.3)\end{array}$ \\
\hline 代謝 · 栄養障害 & $\mathrm{CPK}$ 上昇 & 0 & 0 & 0 & 0 & 1 & 1 & 2 & 4 & 1 & 1 & 2 & $4(21.1)$ \\
\hline $\begin{array}{l}\text { 白血球· } \\
\text { 網内障害 }\end{array}$ & $\begin{array}{l}\text { 白血球数減少 } \\
\text { 好中球数減少 }\end{array}$ & $\begin{array}{l}0 \\
0\end{array}$ & $\begin{array}{l}5 \\
0\end{array}$ & $\begin{array}{l}1 \\
0\end{array}$ & $\begin{array}{l}6 \\
0\end{array}$ & $\begin{array}{l}1 \\
1\end{array}$ & $\begin{array}{l}3 \\
0\end{array}$ & $\begin{array}{l}0 \\
0\end{array}$ & $\begin{array}{l}4 \\
1\end{array}$ & $\begin{array}{l}1 \\
1\end{array}$ & $\begin{array}{l}8 \\
0\end{array}$ & $\begin{array}{l}1 \\
0\end{array}$ & $\begin{array}{c}10(52.6) \\
1(5.3)\end{array}$ \\
\hline
\end{tabular}

注）程度は固形がん化学療法効果増強の判定基準の副作用記載様式に準じた。

表 6. 臨床効果の検討における抗腫瘍効果

\begin{tabular}{c|c|c|c|c|c|c|c}
\hline & 合計 & $\mathrm{CR}$ & $\mathrm{PR}$ & $\mathrm{MR}$ & $\mathrm{NC}$ & $\mathrm{PD}$ & 奏効率 (\%) \\
\hline 例数 & 21 & 3 & 12 & 3 & 2 & 1 & 71.4 \\
\hline
\end{tabular}

効果発現までの期間は 7 日〜 54日, 中央值28日， 平均值26.2土13.7日（S. D.）であった。効果持 続期間においては，CR の奏効期間は63日，212
日 $(+)$ ，228日 $(+), P R$ の奏効期間は29日〜301 日 $(+)$, 中央值74日, 平均值117.0土88.9日 (S. D.) であった。主な副作用は，自他覚症状では 発熱，全身倦怠感などで，臨床検査值異常では 白血球数減少，GOT，GPT 上昇などであった (表 7 )。副作用による中止例は 1 例だけであり， 投与量は 200 万 IU，中止理由は白血球数減少で あった。 
表 7. 副作用一覧（臨床効果の検討）

\begin{tabular}{|c|c|c|c|c|c|c|c|}
\hline & & & \multicolumn{5}{|c|}{ 全 体 } \\
\hline \multicolumn{3}{|c|}{ 例 数 } & \multicolumn{5}{|c|}{22} \\
\hline \multicolumn{3}{|c|}{ 種類/程度 ${ }^{(i)}$} & 1 & 2 & 3 & 4 & 計 (\%) \\
\hline \multirow{5}{*}{$\begin{array}{l}\text { 自 } \\
\text { 他 } \\
\text { 覚 } \\
\text { 的 } \\
\text { 症 } \\
\text { 状 }\end{array}$} & 皮膚·皮膚付属器障害 & 瘙痒感 & 1 & 0 & 0 & 0 & $1(4.5)$ \\
\hline & 中枢・未梢神経系障害 & 頭痛 & 3 & 0 & 0 & 0 & $3(13.6)$ \\
\hline & 消化管障害 & 悪心 & 1 & 0 & 0 & 0 & $1(4.5)$ \\
\hline & 心拍数・心リズム障害 & 不整脈 & 0 & 1 & 0 & 0 & $1(4.5)$ \\
\hline & 一般的全身障害 & $\begin{array}{l}\text { 発熱 } \\
\text { 全身倦怠感 } \\
\text { 悪寒 } \\
\text { 胸部不快感 }\end{array}$ & $\begin{array}{c}10 \\
4 \\
1 \\
1\end{array}$ & $\begin{array}{l}3 \\
3 \\
0 \\
0\end{array}$ & $\begin{array}{l}0 \\
0 \\
0 \\
0\end{array}$ & $\begin{array}{l}0 \\
0 \\
0 \\
0\end{array}$ & $\begin{array}{c}13(59.1) \\
7(31.8) \\
1(4.5) \\
1(4.5)\end{array}$ \\
\hline \multirow{5}{*}{$\begin{array}{c}\text { 臨 } \\
\text { 床 } \\
\text { 検 } \\
\text { 査 } \\
\text { 值 } \\
\text { 異 } \\
\text { 常 }\end{array}$} & 肝臓・胆管系障害 & $\begin{array}{l}\text { GOT 上昇 } \\
\text { GPT 上昇 } \\
\text { LDH 上昇 } \\
\text { ALP 上昇 }\end{array}$ & $\begin{array}{l}5 \\
6 \\
4 \\
1\end{array}$ & $\begin{array}{l}5 \\
0 \\
0\end{array}$ & $\begin{array}{l}0 \\
0 \\
0 \\
0\end{array}$ & $\begin{array}{l}0 \\
0 \\
0\end{array}$ & $\begin{array}{c}13(59.1) \\
11(50.0) \\
4(18.2) \\
1(4.5)\end{array}$ \\
\hline & 代謝・栄養障害 & $\begin{array}{l}\text { CPK 上昇 } \\
\text { アルドラーゼ上昇 } \\
\text { カリウム上昇 }\end{array}$ & $\begin{array}{l}0 \\
1 \\
1\end{array}$ & $\begin{array}{l}2 \\
0 \\
0\end{array}$ & $\begin{array}{l}1 \\
0 \\
0\end{array}$ & $\begin{array}{l}0 \\
0 \\
0\end{array}$ & $\begin{array}{l}3(13.6) \\
1(4.5) \\
1(4.5)\end{array}$ \\
\hline & 白血球・網内系障害 & 白血球数減少 & 2 & 8 & 3 & 1 & $14(63.6)$ \\
\hline & 血小板・出血凝血障害 & 血小板数減少 & 1 & 0 & 0 & 0 & $1(4.5)$ \\
\hline & 泌尿器系障害 & $\begin{array}{l}\text { 血尿 } \\
\text { 尿蛋白 }\end{array}$ & $\begin{array}{l}1 \\
0\end{array}$ & $\begin{array}{l}0 \\
1\end{array}$ & $\begin{array}{l}0 \\
0\end{array}$ & $\begin{array}{l}0 \\
0\end{array}$ & $\begin{array}{l}1(4.5) \\
1(4.5)\end{array}$ \\
\hline
\end{tabular}

注）程度は固形がん化学療法効果増強の判定基準の副作用記載様式に準じ た。

表 8. 後期第 II相試験全体の抗腫瘍効果

\begin{tabular}{c|c|c|c|c|c|c|c}
\hline & 計 & $\mathrm{CR}$ & $\mathrm{PR}$ & $\mathrm{MR}$ & $\mathrm{NC}$ & $\mathrm{PD}$ & 奏効率(\%) \\
\hline 用法用量の検討 & 17 & 0 & 7 & 1 & 8 & 1 & 41.2 \\
臨床効果の検討 & 21 & 3 & 12 & 3 & 2 & 1 & 71.4 \\
\hline 合計 & 38 & 3 & 19 & 4 & 10 & 2 & 57.9 \\
\hline
\end{tabular}

\section{4.抗腫瘍効果のまとめ}

\section{1 ) 奏効率}

試験全体の抗腫瘍効果は，完全例38例中 CR 3 例 PR19例に認められ，奏効率は $57.9 \%$ で あった (表 8 )。内訳は, 用法用量の検討で $41.2 \%$ (7/17例), 臨床効果の検討で71.4\%（15/21例） であった。

\section{2 ) 背景因子別効果}

患者背景因子別効果を表 9 に示す。

Stage ${ }^{13)}$ 別奏効率は, IA が100\% (4/4例), IB
が $61.9 \%$ (13/21例)，IIA が $0 \%(0 / 2$ 例 $)$, IIB が37.5\% (3/8例)，III が100\% (2/2例)，IVB が $0 \%(0 / 1$ 例 $)$ であった。臨床病期別奏効率では, 紅斑期で100\% (4/4例)，扁平浸潤期で $60.0 \%$ (15/25例)，腫瘤期で33.3\% (3/9例) であった。 前治療有無別奏効率は，前治療無しで $68.2 \%$ (15/22)，前治療有りで43.8\%（7/16例）であっ た。前治療ありの症例では, ステロイド, PUVA 療法などの治療で無効または再燃してきた症例 にも効果が認められた。 
表 9.背景因子別抗腫瘍効果一覧表

\begin{tabular}{|c|c|c|c|c|}
\hline \multicolumn{2}{|r|}{ 症例数 } & 評価対象例数 & $P R$ 以上例数 & 奏効率 (\%) \\
\hline \multicolumn{2}{|r|}{ 合計 } & 38 & 22 & 57.9 \\
\hline 性 別 & $\begin{array}{l}\text { 男 } \\
\text { 女 }\end{array}$ & $\begin{array}{l}19 \\
19\end{array}$ & $\begin{array}{l}10 \\
12\end{array}$ & $\begin{array}{l}52.6 \\
63.2\end{array}$ \\
\hline $\begin{array}{l}\text { 年 齢 } \\
\text { (歳) }\end{array}$ & $\begin{aligned} & \sim 40 \\
40 & \sim 49 \\
50 & \sim 59 \\
60 & \sim 69 \\
70 & \sim\end{aligned}$ & $\begin{array}{r}5 \\
10 \\
6 \\
8 \\
9\end{array}$ & $\begin{array}{l}2 \\
6 \\
3 \\
4 \\
7\end{array}$ & $\begin{array}{l}40.0 \\
60.0 \\
50.0 \\
50.0 \\
77.8\end{array}$ \\
\hline P.S. & $\begin{array}{l}0 \\
1 \\
2 \\
3 \\
4\end{array}$ & $\begin{array}{r}34 \\
4 \\
0 \\
0 \\
0\end{array}$ & $\begin{array}{r}20 \\
2 \\
- \\
- \\
-\end{array}$ & $\begin{array}{l}58.8 \\
50.0 \\
- \\
- \\
-\end{array}$ \\
\hline Stage $^{* 1}$ & $\begin{array}{c}\text { I A } \\
\text { I B } \\
\text { II A } \\
\text { II B } \\
\text { III } \\
\text { IVA } \\
\text { IVB }\end{array}$ & $\begin{array}{r}4 \\
21 \\
2 \\
8 \\
2 \\
0 \\
1\end{array}$ & $\begin{array}{r}4 \\
13 \\
0 \\
3 \\
2 \\
- \\
0\end{array}$ & $\begin{array}{r}100.0 \\
61.9 \\
0.0 \\
37.5 \\
100.0 \\
- \\
0.0\end{array}$ \\
\hline 臨床病期 & $\begin{array}{c}\text { 紅斑期 } \\
\text { 扁平浸潤期 } \\
\text { 腫瘤期 }\end{array}$ & $\begin{array}{r}4 \\
25 \\
9\end{array}$ & $\begin{array}{r}4 \\
15 \\
3\end{array}$ & $\begin{array}{r}100.0 \\
60.0 \\
33.3\end{array}$ \\
\hline 合併症 & $\begin{array}{l}\text { 無 } \\
\text { 有 }\end{array}$ & $\begin{array}{l}25 \\
13\end{array}$ & $\begin{array}{c}14 \\
8\end{array}$ & $\begin{array}{l}56.0 \\
61.5\end{array}$ \\
\hline & $\begin{array}{l}\text { 無 } \\
\text { 有 }\end{array}$ & $\begin{array}{l}22 \\
16\end{array}$ & $\begin{array}{r}15 \\
7\end{array}$ & $\begin{array}{l}68.2 \\
43.8\end{array}$ \\
\hline 前治療 & \begin{tabular}{c|c} 
& ステロイド \\
有 & 放射線療法 \\
& 化学療法 \\
& 免疫療法
\end{tabular} & $\begin{array}{r}7 \\
11 \\
0 \\
6\end{array}$ & $\begin{array}{r}3 \\
4 \\
- \\
2\end{array}$ & $\begin{array}{c}42.9 \\
36.4 \\
- \\
33.3\end{array}$ \\
\hline 併用薬泩) & $\begin{array}{l}\text { 無 } \\
\text { 有 }\end{array}$ & $\begin{array}{r}8 \\
30\end{array}$ & $\begin{array}{r}7 \\
15\end{array}$ & $\begin{array}{l}87.5 \\
50.0\end{array}$ \\
\hline 用量 & $\begin{array}{c}100 \text { 万 IU } \\
100 \text { 万ないし } 200 \text { 万 IU } \\
200 \text { IU }\end{array}$ & $\begin{array}{l}12 \\
12 \\
14\end{array}$ & $\begin{array}{l}7 \\
6 \\
9\end{array}$ & $\begin{array}{l}58.3 \\
50.0 \\
64.3\end{array}$ \\
\hline 用法生) & $\begin{array}{l}5 \sim 7 \text { 日/週 } \\
3 \sim 4 \text { 日 } / \text { 週 } \\
1 \sim 2 \text { 日/週 }\end{array}$ & $\begin{array}{r}28 \\
9 \\
1\end{array}$ & $\begin{array}{r}18 \\
4 \\
0\end{array}$ & $\begin{array}{r}64.3 \\
44.4 \\
0.0\end{array}$ \\
\hline $\begin{array}{c}\text { 投与期間 } \\
\text { (週) }\end{array}$ & $\begin{array}{c}\leqq 6 \\
6<\leqq 8 \\
8<\leqq 10 \\
10<\leqq 12 \\
12<\end{array}$ & $\begin{array}{r}9 \\
13 \\
4 \\
1 \\
11\end{array}$ & $\begin{array}{l}4 \\
5 \\
3 \\
1 \\
9\end{array}$ & $\begin{array}{r}44.4 \\
38.5 \\
75.0 \\
100.0 \\
81.8\end{array}$ \\
\hline
\end{tabular}

注）併用薬：解熱剂等 放射線療法：PUVA 療法を含む

Stage：Bunn の分類

用 法：PR 以上の症例は PR 開始時点までの投与頻度を，それ以外 の症例は全投与期間を通じての投与頻度を使用した。 
投与量別奏効率では，100万 IU で58.3\%（7/ 12例)，100万ないし 200 万 IU で50.0\%（6/12 例)，200万 IU で64.3\%（9/14例）であった。

投与頻度別奏効率では，ほとんどの症例で週 3 日以上投与されており，間欠投与（週 $1 \sim 2$ 日 投与） で $0 \%(0 / 1$ 例)，隔日投与（週3〜 4日投 与） で $44.4 \%(4 / 9$ 例), 連日投与（週 5 日以上 投与）で $64.3 \%(18 / 28$ 例）と，隔日投与に比べ 連日投与で高かった。

\section{3 ) 効果発現までの期間}

奏効例における効果発現までの期間を，投与 開始から PR 開始時点までの期間でみると， 7 119日, 中央值28日, 平均值32.0土22.9日 (S. D.）であった。ステージ別，臨床病期別，投与 量別の効果発現までの期間を表10に示す。ス テージや臨床病期の進行および投与量いずれに おいても効果発現までの期間との関係は特に認 められなかった。

\section{4 ）効果持続期間}

奏効例における効果持続期間は， $\mathrm{CR} の$ 奏効 期間で63日，212日 $(+) ， 228$ 日 $(+) ， P R$ の奏 効期間で29 301日 $(+)$, 中央值74日，平均值
$105.0 \pm 80.5$ (S. D.) であった。ステージ別, 臨 床病期別, 投与量別の PR 効果持続期間を, 表11 に示す。ステージや臨床病期の進行に伴い効果 持続期間がやや短くなる傾向がみられたが，投 与量と効果持続期間との関係は特に認められな かった。

\section{5. 副作用のまとめ}

適格例41例の副作用を表12に示す。41例中39 例 $(95.1 \%)$ に何らかの副作用が発現し，自他 覚症状として, 発熱 $(70.7 \%)$, 全身倦怠感 (48.7\%) などが，臨床検查值異常として，白血 球数減少 $(58.5 \%), \mathrm{GOT}$ 上昇 $(51.2 \%), \mathrm{GPT}$ 上昇（43.9\%）などが認められた。これらの副 作用で重篤なものは無く，いずれも可逆性のも のであった。また，最も高頻度に発現した発熱 は解熱剂等の処置でコントロール可能であり, 発熱による中止例は 1 例も無かった。

副作用による中止例は 3 例で, 投与量は 100 万 IU が 1 例, 200 万 IU が 2 例であり，中止理由は 全身倦怠感が 1 例, 白血球数減少および GOT. GPT 上昇が 1 例, 白血球数減少が 1 例であっ た。全身倦点感で投与を中止した 1 例は,グレー

表10. 背景因子別効果発現までの期間

\begin{tabular}{|c|c|c|c|c|c|c|}
\hline \multicolumn{2}{|c|}{ 背景因子 } & ～14日 & 15 28日 & 29 42日 & $43 \sim 56$ 日 & 57日〜 \\
\hline \multirow{7}{*}{$\begin{array}{c}\text { ス } \\
\bar{\tau} \\
1 \\
\text { シ }\end{array}$} & I A & 0 & 2 & 2 & 0 & 0 \\
\hline & I B & 3 & 4 & 5 & 1 & 0 \\
\hline & II A & 0 & 0 & 0 & 0 & 0 \\
\hline & II B & 0 & 2 & 0 & 0 & 1 \\
\hline & III & 1 & 0 & 1 & 0 & 0 \\
\hline & IVA & 0 & 0 & 0 & 0 & 0 \\
\hline & IVB & 0 & 0 & 0 & 0 & 0 \\
\hline \multirow{3}{*}{$\begin{array}{l}\text { 臨 } \\
\text { 床 } \\
\text { 病 } \\
\text { 期 }\end{array}$} & 紅斑期 & 0 & 2 & 1 & 1 & 0 \\
\hline & 扁平浸潤期 & 4 & 4 & 7 & 0 & 0 \\
\hline & 腫瘍期 & 0 & 2 & 0 & 0 & 1 \\
\hline \multirow{3}{*}{$\begin{array}{c}\text { 用 } \\
\text { 量 } \\
\text { (万IU) }\end{array}$} & 100 & 2 & 2 & 2 & 1 & 0 \\
\hline & $100 \sim 200$ & 0 & 3 & 2 & 0 & 1 \\
\hline & 200 & 2 & 3 & 4 & 0 & 0 \\
\hline
\end{tabular}


表11. 背景因子別 PR 奏効期間

\begin{tabular}{|c|c|c|c|c|c|c|}
\hline \multicolumn{2}{|c|}{ 背景因子 } & $\sim 56$ 日 & $57 \sim 112$ 日 & 113 168日 & 169 224日 & 225日 \\
\hline \multirow{7}{*}{$\begin{array}{l}\text { ス } \\
\bar{\tau} \\
1 \\
\forall\end{array}$} & I A & 1 & 2 & 0 & 1 & 0 \\
\hline & I B & 4 & 3 & 2 & 2 & 2 \\
\hline & II A & 0 & 0 & 0 & 0 & 0 \\
\hline & IIB & 1 & 1 & 1 & 0 & 0 \\
\hline & III & 1 & 1 & 0 & 0 & 0 \\
\hline & IVA & 0 & 0 & 0 & 0 & 0 \\
\hline & IVB & 0 & 0 & 0 & 0 & 0 \\
\hline \multirow{3}{*}{$\begin{array}{l}\text { 臨 } \\
\text { 病 } \\
\text { 期 }\end{array}$} & 紅斑期 & 1 & 0 & 0 & 2 & 1 \\
\hline & 扁平浸潤期 & 5 & 6 & 2 & 1 & 1 \\
\hline & 腫瘍期 & 1 & 1 & 1 & 0 & 0 \\
\hline \multirow{3}{*}{$\begin{array}{c}\text { 用 } \\
\text { 量 } \\
\text { (万IU) }\end{array}$} & 100 & 1 & 3 & 2 & 0 & 1 \\
\hline & $100 \sim 200$ & 2 & 2 & 1 & 1 & 0 \\
\hline & 200 & 4 & 2 & 0 & 2 & 1 \\
\hline
\end{tabular}

ド 1 の全身倦怠感のため中止したが，処置はボ ルタレン投与のみで投与中止後 7 日目に消失し ている。また，白血球数減少および $\mathrm{GOT} \cdot \mathrm{GPT}$ 上昇のため投与を中止した 1 例は, 白血球数が 2000/ $\mathrm{mm}^{3}$, GOT が82U, GPT が46U となった が，特に処置は要せずいずれも投与中止後11日 目に回復している。白血球数減少のため投与を 中止した 1 例は，白血球数が $900 / \mathrm{mm}^{3}$ にまで減 少したが，G-CSF の投与により中止後13日目 に回復している。

\section{6. 抗体価}

抗 IFN- $\gamma$ 抗体価および抗異種蛋白抗体価を 32例について投与前後に測定した結果，全て陰 性であった。

\section{7. 血清中 IFN $-\gamma$ 濃度}

菌状息肉症患者における血清中 IFN- $\gamma$ 濃度 (RIA 法) を図 1 に示す。初回投与時， 1 週間後 および 2 週間後における血清中濃度推移は同様 であり, 反復投与による変化は認められなかった。

\section{8. 免疫学的検査}

$\beta_{2}$-ミクログロブリンとネオプテリンで有意

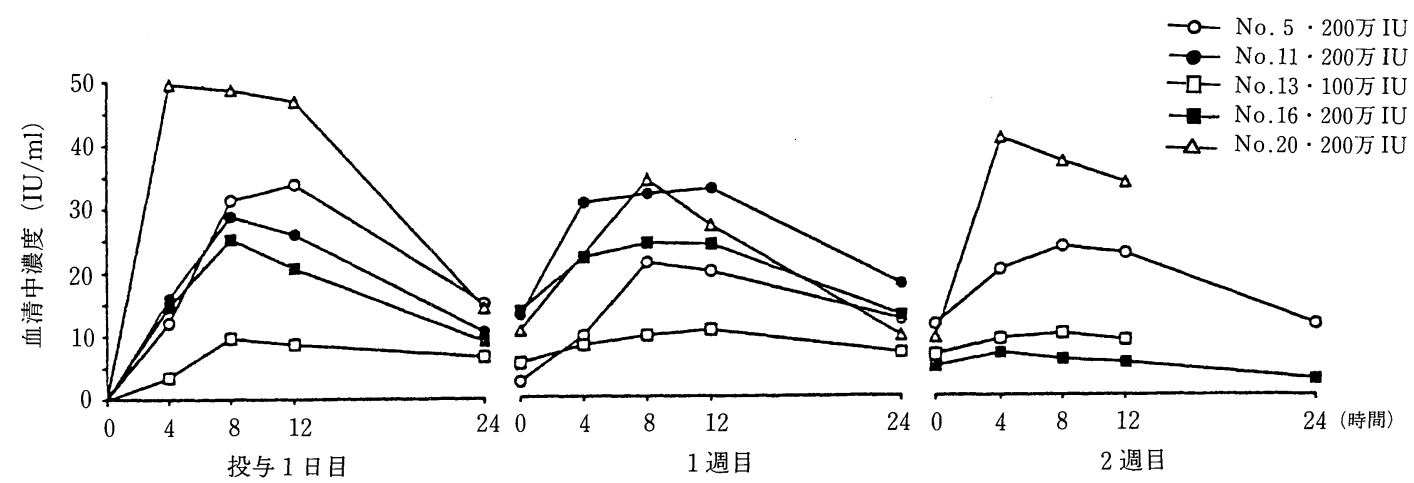

図 $1 \mathrm{OH}-6000$ を菌状息肉症患者に 1 日 1 回 2 週間反復筋肉内投与した場合の血清中濃度推移 
表12. 後期第 II相試験全体の自他覚症状, 臨床検査值異常

\begin{tabular}{|c|c|c|c|c|c|c|}
\hline & \multirow{2}{*}{\multicolumn{2}{|c|}{$\frac{\text { 安全性評価対象例 }}{\text { 因果関係 }}$}} & \multicolumn{4}{|c|}{41} \\
\hline & & & 有 $(\%)$ & 不明 $(\%)$ & 計 $(\%)$ & 無 $(\%)$ \\
\hline \multicolumn{3}{|c|}{ 副作用発現例数 } & \multicolumn{4}{|c|}{39} \\
\hline \multicolumn{3}{|c|}{ 副作用発現率 (\%) } & \multicolumn{4}{|c|}{95.1} \\
\hline \multicolumn{3}{|c|}{ 副作用発現件数 } & 138 & 13 & 151 & 4 \\
\hline \multirow{7}{*}{ 自 } & 皮膚 - 皮䖉付属器障害 & $\begin{array}{l}\text { 発疹 } \\
\text { 瘦痒感 } \\
\text { 萇麻疹 }\end{array}$ & $\begin{array}{l}1(2.4) \\
0(0.0) \\
0(0.0)\end{array}$ & $\begin{array}{l}0(0.0) \\
1(2.4) \\
0(0.0)\end{array}$ & $\begin{array}{l}1(2.4) \\
1(2.4) \\
0(0.0)\end{array}$ & $\begin{array}{l}0(0.0) \\
0(0.0) \\
1(2.4)\end{array}$ \\
\hline & 筋・骨格系障害 & $\begin{array}{l}\text { 関節痛 } \\
\text { ひざ関節痛 } \\
\text { 瘙痒 } \\
\text { 肩こり }\end{array}$ & $\begin{array}{l}1(2.4) \\
0(0.0) \\
0(0.0) \\
0(0.0)\end{array}$ & $\begin{array}{l}0(0.0) \\
0(0.0) \\
0(0.0) \\
0(0.0)\end{array}$ & $\begin{array}{l}1(2.4) \\
0(0.0) \\
0(0.0) \\
0(0.0)\end{array}$ & $\begin{array}{l}0(0.0) \\
1(2.4) \\
1(2.4) \\
1(2.4)\end{array}$ \\
\hline & 中枢·末梢神経系障害 & 頭痛 & $3(7.3)$ & $2(4.9)$ & $5(12.2)$ & $0(0.0)$ \\
\hline & 消化管障害 & $\begin{array}{l}\text { 悪心 } \\
\text { 食欲不振 } \\
\text { 腹部不快感 }\end{array}$ & $\begin{array}{l}2(4.9) \\
1(2.4) \\
1(2.4)\end{array}$ & $\begin{array}{l}1(2.4) \\
0(0.0) \\
0(0.0)\end{array}$ & $\begin{array}{l}3(7.3) \\
1(2.4) \\
1(2.4)\end{array}$ & $\begin{array}{l}0(0.0) \\
0(0.0) \\
0(0.0)\end{array}$ \\
\hline & 心拍数・心リズム障害 & 不整脈 & $1(2.4)$ & $0(0.0)$ & $1(2.4)$ & $0(0.0)$ \\
\hline & 一般的全身障害 & $\begin{array}{l}\text { 発熱 } \\
\text { 全身倦怠感 } \\
\text { 悪寒 } \\
\text { 胸部不快感 }\end{array}$ & $\begin{array}{r}28(68.3) \\
18(46.2) \\
1(2.4) \\
0(0.0)\end{array}$ & $\begin{array}{l}1(2.4) \\
1(2.4) \\
0(0.0) \\
1(2.4)\end{array}$ & $\begin{array}{r}29(70.7) \\
19(48.7) \\
1(2.4) \\
1(2.4)\end{array}$ & $\begin{array}{l}0(0.0) \\
0(0.0) \\
0(0.0) \\
0(0.0)\end{array}$ \\
\hline & 適用部位障害 & 投与部熱感 & $1(2.4)$ & $0(0.0)$ & $1(2.4)$ & $0(0.0)$ \\
\hline \multirow{5}{*}{$\begin{array}{l}\text { 臨 } \\
\text { 床 } \\
\text { 検 } \\
\text { 査 } \\
\text { 值 } \\
\text { 異 } \\
\text { 常 }\end{array}$} & 肝臓・胆管系障害 & $\begin{array}{l}\text { GOT 上昇 } \\
\text { GPT 上昇 } \\
\text { LDH 上昇 } \\
\text { ALP 上昇 }\end{array}$ & $\begin{array}{r}20(48.8) \\
17(41.5) \\
8(19.5) \\
2(4.9)\end{array}$ & $\begin{array}{l}1(2.4) \\
1(2.4) \\
0(0.0) \\
0(0.0)\end{array}$ & $\begin{array}{r}21(51.2) \\
18(43.9) \\
8(19.5) \\
2(4.9)\end{array}$ & $\begin{array}{l}0(0.0) \\
0(0.0) \\
0(0.0) \\
0(0.0)\end{array}$ \\
\hline & 代謝·栄養障害 & $\begin{array}{l}\mathrm{CPK} \text { 上昇 } \\
\text { アルドラーゼ上昇 } \\
\text { カリウム上昇 }\end{array}$ & $\begin{array}{l}6(14.6) \\
1(2.4) \\
0(0.0)\end{array}$ & $\begin{array}{l}1(2.4) \\
0(0.0) \\
1(2.4)\end{array}$ & $\begin{array}{l}7(17.1) \\
1(2.4) \\
1(2.4)\end{array}$ & $\begin{array}{l}0(0.0) \\
0(0.0) \\
0(0.0)\end{array}$ \\
\hline & 白血球・網内系障害 & $\begin{array}{l}\text { 好中球数減少 } \\
\text { 白血球数減少 }\end{array}$ & $\begin{array}{r}1(2.4) \\
23(56.1)\end{array}$ & $\begin{array}{l}0(0.0) \\
1(2.4)\end{array}$ & $\begin{array}{r}1(2.4) \\
24(58.5)\end{array}$ & $\begin{array}{l}0(0.0) \\
0(0.0)\end{array}$ \\
\hline & 血小板 - 出血凝血障害 & 血小板数減少 & $0(0.0)$ & $1(2.4)$ & $1(2.4)$ & $0(0.0)$ \\
\hline & 泌尿器系障害 & $\begin{array}{l}\text { 尿蛋白 } \\
\text { 血尿 }\end{array}$ & $\begin{array}{l}1(2.4) \\
1(2.4)\end{array}$ & $\begin{array}{l}0(0.0) \\
0(0.0)\end{array}$ & $\begin{array}{l}1(2.4) \\
1(2.4)\end{array}$ & $\begin{array}{l}0(0.0) \\
0(0.0)\end{array}$ \\
\hline
\end{tabular}

の上昇がみられた(図 2)。その他の項目では特 に大きな変動はみられなかった。

\section{考察}

菌状息肉症はへルパーT cell マーカーを有す る腫瘍で臨床的に長期間皮膚のみに病変が限局 し，やがて免疫能の低下とともに全身に病変が 出現し死の転帰をとる腫瘍である ${ }^{14)}$ 。一般に慢
性の経過をとるが，治癒は期待できないといわ れる。臨床所見としては，通常皮膚病変が先行 し, 紅斑, 浸潤, 腫瘤の症状が経時的に変化す るか，あるいはそれらの症状が混在して長期間 継続する。そしてやがては全身に病変が拡大し て死の転帰をとるか，もしくは免疫不全状態を 惹起して合併症（たとえば急性肺炎，カリ二肺 炎，下痢腸炎など）により死亡する ${ }^{15)}$ 。なお，本 症は紅斑期であっても病理組織学的に確認され 

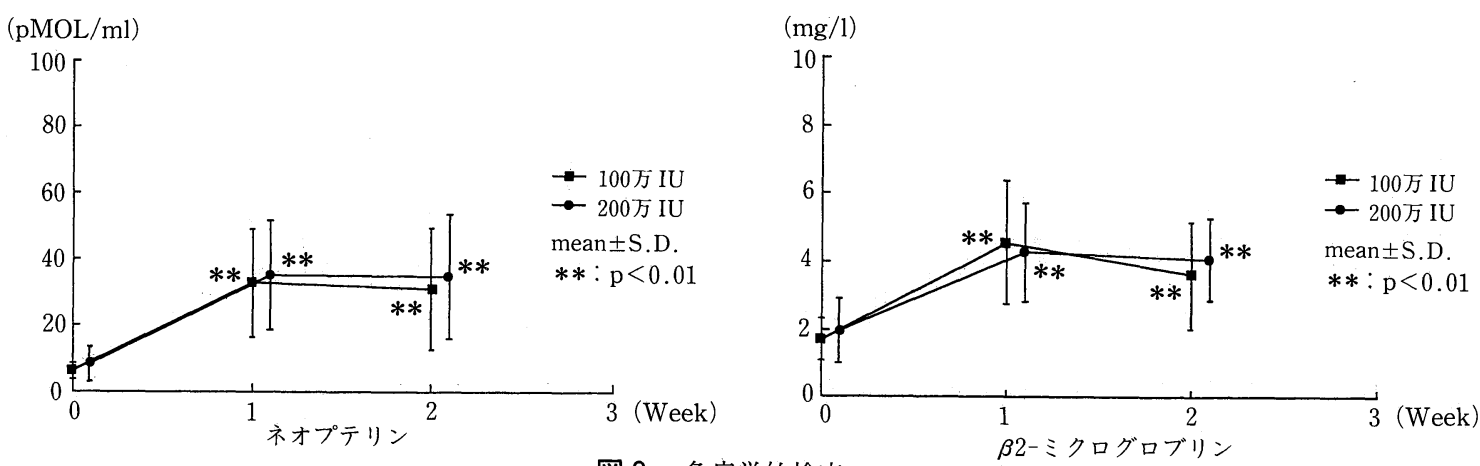

図 2 免疫学的検査

たものであり，かつ臨床的に症状が固定された ものであるが，一般に長期間リンパ節，血液お よび内臟に病変を認めない状態が続く。

菌状息肉症の治療は, 本症が他の悪性リンパ 腫と異なり極めて慢性の経過をたどること，末 期になって初めて内藏に病変が出現すること, 化学療法の効果は他のリンパ腫に比べて低いこ と, 徐々に免疫能力が低下するためこれを助長 するような治療はなるべく早期から使用しない こと ${ }^{15)} よ り ，$ 早期にはステロイド外用，PUVA 療法および放射線療法などの局所療法が多く, 晚期には強力な多剂併用化学療法が一般的であ る。しかし, PUVA 療法などの局所療法では皮 下の病変には効果が期待できない16)など全身的 効果は不十分であり，再発率も高いことが指摘 されている ${ }^{17)}$ 。一方, 化学療法は末血やリンパ節 に対しては比較的よく反応するのに対して皮膚 に対する反応が悪いという点が問題であり ${ }^{18)}$, 骨髄抑制，感染症の併発等の重篤な副作用を高 率に生じ生存期間の延長には結びついていない といわれている(14)16)19)。このように, 現在の菌状 息肉症に対する治療法は一定の効果は有るがい ずれの治療法でも完治することはなく，必ずし も満足のいくものではない。そこで，新しい治 療の試みがなされており, その中で最も期待さ れているものの1つにBRM (Biological Response Modifiers）がある。

$\mathrm{OH}-6000$ は天然型 IFN- $\gamma$ であり，既に各種 悪性腫瘍を対象にした前期第 II 相試験で菌状
息肉症に対して効果があることが示唆されてお $\eta$ ，投与量として効果は 100 万 IUより認めら れ，投与量の上限は耐容性より200万 IU までが 適当と判断された。そこで，更に本疫患につい て用法用量の検討と有効性や安全性の程度を確 定することを目的にした後期第 II 相試験を実 施した。

まず用法用量の検討を行った。その結果抗腫 瘍効果は 100 万 IU 投与群で 8 例中 PR 3 例奏 効率 $37.5 \%, 200$ 万 IU 投与群で 7 例中 PR 3 例 奏効率 $42.9 \%$ と大きな差はみられなかった。た だし, 100万 IUを 8 週間投与したが効果 MR の ため 4 週間の休薬後 200 万 IU を投与し効果 $\mathrm{PR}$ を得た症例が 1 例みられた。副作用は GOT, GPT, LDH，CPK の上昇で200万 IU 群の方が 100万 IU 群に比べて発現頻度がやや高かった。 また，投与頻度別の奏効率をみると，週に 5 日 以上の連日投与では $45.5 \%$ (5/11例), 週に 3 〜 4 日の隔日投与では $33.3 \%(2 / 6$ 例) と，連日 投与で高かった。更に効果発現までの期間は, 20〜119日であった。以上のことから，本剤の臨 床効果を検討するための適切な用法用量として 1 日 1 回 100 万 IU あるいは 200 万 IU を副作用, 病勢により適宜増減しながら原則として連日筋 肉内投与し，かつ投与期間は原則として 8 週間 以上とすることが適当であると判定委員会で結 論された。

そこで, 更にこの臨床用法用量にて本剂の抗 腫瘍効果を検討した結果，21例中 CR 3 例, 
PR12例, 奏効率 $71.4 \%$ と高い奏効率が認められ た。用法用量の検討例に比べて臨床効果の検討 例で奏効率が高かった理由として，患者背景と 投与方法の違いが考えられた。すなわち，臨床 効果の検討例に比べて用法用量の検討例では, ステージや臨床病期の進行した症例が多く，前 治療有りの症例も多かった。さらに投与方法之 して, 用法用量の検討では原則として用量が100 万IUもしくは200万IU のいずれかに固定され ていたことに比べて, 臨床効果の検討では 100 万 IU あるいは 200 万 IU を副作用，病勢により適 宜増減するという方法で行ったことにより個々 の症例に応じた対応が可能になったため，臨床 効果の検討例で 8 週間を越えた長期投与例や週 5 日以上の連続投与例が多かった。これらの要 因が密接に関連したことにより，奏効率に違い が生じたものと考えられた。

本剂の抗腫瘍効果を詳細に検討すると, 前治 療有りの症例に対する奏効率は $43.8 \%(7 / 16)$ であり，ステロイド外用，PUVA 療法などの治 療で無効または再燃してきた症例にも効果が認 められている。また, Stage では I からIIIの症例 で, 臨床病期では紅斑期, 扁平浸潤期, 腫瘤期 の症例で効果が認められている。

副作用は, 自他覚症状として, 発熱, 全身倦 急感などが, 臨床検査值異常として，白血球数 減少, GOT, GPT 上昇などが認められたが，こ れらは既に報告されているIFN- $\gamma$ の副作 用5220221) と類似のものであり，本剂に特有なもの は認められなかった。さらにこれらの副作用で 重篤なものは無くいずれも可逆性のものであ ク, 安全性の高い薬剂であることが確認された。

このように OH-6000は菌状息肉症に対して, 全身投与で高い奏効率を示し，前治療の有無や Stage, 臨床病期の進行の程度によらず効果が 認められたことより，優れた抗腫瘍効果を有す ることが確認され，かつ安全性が高く，筋肉内 投与であることにより外来でも投与しやすく， 長期にわたって使用しやすい極めて有用な薬剤 であるといえる。
IFN の菌状息肉症に対する抗腫瘍効果発現 機序については，未だ不明な点が多い。菌状息 肉症由来の細胞株が樹立されていない現状で は, 本剤の $\mathrm{T}$ リンパ性白血病細胞株に対する直 接的な細胞増殖抑制作用, 単球, NK 細胞の殺腫 瘍活性の増強作用22)や今回の試験で認められた class 1 抗原の 1 部である $\beta 2$ ミクログロブリ ンの誘導作用等の宿主介在性の免疫増強作用な ど，これらの作用が密接に関与しあってその抗 腫瘍効果を発揮しているものと推察される。

一方，他の BRM の菌状息肉症に対する成績 をみると, IFN- $\gamma$ については既に遺伝子組換え 型での検討がなされている。著者らによると ${ }^{20)}$, 点滴静注で菌状息肉症26例に投与して CR2例, PR13例 (奏効率57.7\%), 奏効期間31～254日 (中 央值85日)であったとし, Edward ら ${ }^{21)}$ は同じく 遺伝子組換え型 IFN- $\gamma$ を筋肉内投与で皮膚 T 細胞リンパ腫16例に投与して PR5例（奏効率 $31 \%)$ ，奏効期間3 32 力 $(+)$ (中央値10力月） を報告しているが，いずれの成績と比較しても 今回同様なステージ，臨床病期の症例で行った 本剂の臨床効果の検討における奏効率 $(71.4 \%)$ は優れたものといえる。この奏効率の違いは同 じ IFN- $\gamma$ でも天然型と遺伝子組換之型の違い によるものか用法用量の違いによるものかなど は不明である。遺伝子組換え型 IFN-

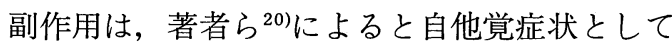
発熱 $(78.7 \%)$, 悪寒 $(46.8 \%)$, 戦慄 $(31.9 \%)$, 全身倦急感 $(46.8 \%)$, 頭痛 $(21.3 \%)$ ，食欲不 振 $(21.3 \%)$ および悪心/おう吐 $(31.9 \%)$ が, 臨床検查值異常として白血球減少 $(29.8 \%)$, 好 中球減少 $(37.0 \%), \mathrm{GOT}$ 上昇 $(31.9 \%)$ 拈上 び GPT 上昇 $(27.7 \%)$ がみられたとし, Edward ら ${ }^{21)}$ は自他覚症状として発熱 $\left(37.7^{\circ} \mathrm{C}\right.$ 以上の発 熱，69\%）拈よび体重減少（体重の5\%を越之 る減少，38\%）が，臨床検查值異常として好中 球減少 $\left(2500 / \mathrm{mm}^{3}\right.$ 以下， $\left.38 \%\right), \mathrm{LDH}$ 上昇 (100\%) およびGOT 上昇（100\%）が認められ たと報告している。今回の試験で認められた OH-6000の自他覚症状や臨床検査值異常は，こ 
れら既に報告されているIFN- $\gamma$ のそれと種類 および頻度に大きな差はなく, 特に問題となる ような新たなものも認められていない。

$\mathrm{IFN}-\gamma$ 以外の BRM として IFN- $\alpha-2 \mathrm{a}$ につ いては，海外で菌状息肉症を中心とする皮膚 $\mathrm{T}$ 細胞リンパ腫に対して筋肉内または皮下投与が なされ，奏効率は29～ $80 \%$ と報告されてお ク 23) 27), 国内においては池田ら ${ }^{28)} に よ り$ 菌状息 肉症 22 例に筋肉内投与した結果, PR 11例(奏効 率50\%）であったが CR 例は認められなかった と報告している。

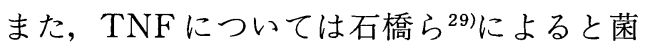
状息肉症 21 例に静脈内投与した結果, CR 1 例, PR 6 例（奏効率33.3\%）が認められたにとど まっている。

これら各種 BRMの成績と比較して, 今回得 られた OH-6000の成績は最も優れたものの 1 つと思われる。今後は, 菌状息肉症における更 なる治療成績向上のために $\mathrm{OH}-6000$ とこれら の BRM や化学療法, PUVA 療法および放射線 療法などの既存の治療法との適切な併用による 検討が期待される。

\section{結 論}

天然型 IFN- $\gamma(\mathrm{OH}-6000)$ について，菌状息 肉症患者を対象として後期臨床第 II 相試験を 実施し, 以下の成績が得られた。

1 ）用法用量を検討した結果, 1 日 1 回 100 万 IU あるいは200万 IU を副作用, 病勢により適 宜増減しながら筋肉内投与することが望ましい と結論された。

2 ）試験全体の抗腫瘍効果は, 完全例38例中 CR 3 例 PR 19例に認められ，奏効率は $57.9 \%$ であった。内訳は, 用法用量の検討で $41.2 \%$ (7) 17例), 臨床効果の検討で $71.4 \%$ (15/21例) で あった。

3 ）副作用は，既に報告されている $\mathrm{IFN}^{-} \gamma$ のそれと類似であり，特に重篤なものもなく， すべて可逆性であった。
以上のことより，OH-6000は菌状息症に対し て極めて有用性の高い薬剤であることが確認さ れた。

\section{文献}

1) Isaacs, A., Lindenmann, J. : Virus interference. I. The interferon. Proc. R Soc. Ser. B., $147: 258$ $-267,1957$.

2) Stewart, W. E.: Interferon nomenclature. Nature, $286: 110,1980$.

3 ) Branca, A. A., Baglioni, C.: Evidence that types I and II interferons have different receptors. Nature, 294 : 768-770, 1981.

4 ) Rubin, B. Y., Gupta, S. : Differential efficacies of human type I and type II interferons as antiviral and antiproliferative agents. Proc. Natl. Acad. Sci. USA, 77 (10) : 5928-5932, 1980.

5 ）高久史麿：悪性腫瘍に対する遺伝子組換え七トイ ンターフェロン $\gamma(\mathrm{S}-6810)$ の治療効果. 癌と化 学療法, 14 (3)：645-652, 1987.

6 ) 神前五郎：遺伝子組換えヒトインターフェロンガ ンマ(SUN 4800)の各種悪性腫揚に対する早期臨 床第 II 相試験. BIOTHERAPY, 3(4)：829-838, 1989.

7 ) Ando, S., Ohta, T., Tanimoto, T., et al. : Natural Human Interferon- $\gamma$ Derived from Lipopolysaccharide-stimulated Human Myelomonocytic HBL-38 Cells. Jpn. J. Cancer Res. (Gann), 79 (6) : 757-765, 1988.

$8)$ Yamamoto, S., Hase, S., Fukuda, S., et al.: Structures of the Sugar Chains of Inteferon -Produced by Human Myelomonocyte Cell Line HBL-38. J. Biochem., 105 (4) : 547-555, 1989.

9 ) 古江尚：悪性腫瘍に対する天然型 IFN- $\gamma(\mathrm{OH}$ $-6000)$ 前期臨床第 II 相試験. BIOTHERAPY 投 稿予定

10）小山善之, 斎藤達雄：日本癌治療学会固形がん化 学療法効果判定基準. J. Jpn. Soc. Cancer Ther., 21 (5) : 929-942, 1986.

11）石原和之, 池田重雄, 荒尾龍喜, 他: 皮膚悪性腫 瘍に扔ける固形がん薬物療法効果判定基準. J. Jpn. Soc. Cancer Ther., 25 (11) : 2609-2620, 1990.

12）小山善之, 斎藤達雄：日本癌治療学会固形がん化 学療法効果增強の判定基準. J. Jpn. Soc. Cancer Ther., 21 (5) : 943-953, 1986.

13) Bunn, P.A., Lamberg, S.I. : Report of the Committee on Staging and Classification of Cutaneous T-Cell Lymphomas. Cancer Treat. Rep., 63 : 725-728, 1979.

14）石原和之, 池田重雄：皮䖉悪性腫瘍における評価 法, とくに局所投与について. Skin Cancer, $3: 14$ $-18,1988$.

15）石原和之：皮膚 $\mathrm{T}$ 細胞リンパ腫. 医学のあゆみ, 146 (4): 200-202, 1988.

16）中島弘，宮本秀明：皮膚の悪性リンパ腫．癌と化 学療法, 12 (9)：1735-1743, 1985. 
17) Bunn, P. A., Carney, D. N.: Treatment of Cutaneous T-Cell Lymphoma. J. Dermatol. Surg. Oncol., $6: 383-387,1980$.

18）長谷哲男, 中嶋弘：抗腫瘍療法一皮膚の悪性リン 八腫一. 医学と薬学, 19 (2) : 267-273，1988.

19）岩月啓氏，山田瑞穂：皮膚のリンフォーマの治療 と展望. 日皮会誌，97（12）：1388-1390， 1987.

20）石原和之, 池田重雄, 森俊二, 他：皮膚悪性腫瘍 における SUN4800後期臨床第 II 相試験. 西日皮 膚, 51 (4) : 766-775, 1989.

21) Kaplan, E. H., Rosen, S. T., Norris, D. B., et al. : Phase II Study of Recombinant Human Interferon Gamma for Treatment of Cutaneous $\mathrm{T}$ -Cell Lymphoma. J. Natl. Cancer Inst., 82 : 208 $-212,1990$.

22）十河真司, 他：臨床医薬 投稿予定

23) Bunn, P. A., Foon, K, A., Ihde, D. C., et al.: Recombinant Leukocyte A Interferon: An Active Agent in Advanced Cutaneous T-Cell Lymphomas. Ann. Intern. Med., 101 : 484-487, 1984.

24) Bunn, P. A., Ihde, D. C., Foon, K. A. : The Role of Recombinant Interferon Alfa-2a in the
Therapy of Cutaneous T-Cell Lymphomas. Cancer, 57 : 1689-1695, 1986.

25) Tura, S., Mazza, P., Zinzani, P. L., et al. : Alpha Recombinant Interferon in the Treatment of Mycosis Fungoides (MF). Haematologica, 72 : 337-340, 1987.

26) Olsen, E. A., Rosen, S. T., Vollmer, R. T., et al. : Interferon alfa-2a in the treatment of cutaneous T-cell lymphoma.J. Am. Acad. Dermatol., 20 : 395-407, 1989.

27) Kohn, E. C., Steis, R. G., Sausville, E. A., et al. : Phase II Trial of Intermittent High-Dose Recombinant Interferon Alfa-2a in Mycosis Fungoides and the Sezary Syndrome. J. Clin. Oncol., 8: 155-160, 1990.

28）池田重雄, 石原和之：インターフェロンアルファ -2a（遺伝子組換之）の皮膚悪性腫瘍に対する臨床 試験. Skin Cancer, 7 (3) : 389-403, 1992.

29）石橋康正，石原和之，大原国章，他：皮虐悪性腫 瘍に対する MHR-24 (天然型七ト腫瘍壊死因子) の臨床第 II 相試験. 臨床医薬, 8(4)：775-792, 1992. 